\title{
EDITORIAL: TIME TO MOVE FORWARD ON INTERNATIONAL ICT LAW
}

\author{
by \\ DAN JERKER B. SVANTESSON ${ }^{*}$
}

Anyone studying the comparatively short history of the discipline we may refer to as information and communications technology (ICT) law will notice several trends. One such trend is that, where a new topic starts gaining attention, that attention is typically directed at the domestic context. For example, it is only relatively recently that the international dimensions of data privacy law have started to gain widespread attention, and areas such as cyber security are still mainly approached from a domestic perspective.

This is not to deny that there, already early on, is an awareness of the international dimensions. All I am suggesting here is that those international dimensions only gain widespread attention once the domestic perspective has been pursued. And maybe this is both natural and desirable. However, what is striking is the extent to which attention is now being directed at the international dimensions of various topics falling within the umbrella term of ICT law. In fact, I think we are now in a "golden era" for anyone who has an interest in the cross-section of ICT law and international law - be it public, or private, international law (to the extent that distinction still is valid).

In light of this, this special issue of the Masaryk University's flagship journal - the Masaryk University Journal of Law and Technology (MUJLT) - is definitely timely. And given the high quality of the contributions, and the interesting topics they address, I have no doubt that this issue will help progress the law on several vitally important topics. Because the time

dasvante@bond.edu.au, Professor and Co-Director, Centre for Commercial Law, Faculty of Law, Bond University, Australia; Researcher, Swedish Law \& Informatics Research Institute, Stockholm University, Sweden. 
has come to take some serious steps forward on how we approach the international dimensions of ICT law.

Revolidis sets a high standard with his fascinating account of jurisdiction over privacy violations, with special focus on the impact of art.79(2) of the General Data Protection Regulation, which opens this issue. This is followed by excellent contributions addressing diverse topics within the field of international ICT law. Van Cleynenbreugel discusses the European Commission's geo-blocking proposals and the future of EU e-commerce regulation, Gonçalves addresses choice-of-court agreements in international e-commerce contracts, and Maunsbach provides an innovative perspective on the development of Internet related case-law within the Court of Justice of the European Union. Thereafter, we see the fruits of the collaboration between Osula and Zoetekouw in the form of their article focused on the notification requirement embedded into the legal regimes regulating remote search and seizure. We then have Stadnik's exploration of international cybersecurity regimes and Žolnerčíková's account of ICANN's recent transformation. The issue ends with Bogdan's comment on the new EU Regulation No 2015/848 on Insolvency Proceedings (Recast) that create a system of national insolvency registers and establish a decentralized system for the interconnection of such registers by means of the European e-Justice Portal.

All the contributions that appear in this issue stem from two events held in November 2016. The first of those events is the 2016 rendition of the highly successful conference series on interdisciplinary cyberspace issues held annually at the Masaryk University. I take this opportunity to thank the organisers of Cyberspace 2016 and especially the participants in the international ICT law work stream.

The second of the events from which the contributions to the special issue stem is a workshop organised by the European Law Institute's Intellectual Property Law Special Interest Group together with the Centre for Commercial Law at Bond University. The workshop was held at the University of Vienna and was funded by the Australian Research Council (ARC) as part of a project - an Australian Research Council Future Fellowship - I held at the time which reassessed and re-evaluated how the concept of jurisdiction most appropriately can be applied in the Internet 
era characterised by cloud computing, Web 2.0 and geo-location technologies. I thank all involved in the Vienna workshop.

I feel privileged to have had the opportunity to - for a second time - be the Guest Editor for a special issue of the MUJLT. I thank all who have worked on this issue, especially the Editor-in-Chief Radim Polčák, the Deputy Editor-in-Chief Jakub Harašta and, of course, the crucially important and superbly qualified authors.

Dan Jerker B. Svantessson 18 June 2017, Mudgeeraba, Australia 